\title{
The Neutral and Alkaline Proteases of Aspergillus nidulans
}

\author{
By B. L. COHEN \\ Department of Genetics, University of Glasgow, Glasgow, GI I $5 J S$
}

(Received 9 March 1973)

\begin{abstract}
SUMMARY
When grown on glucose salts medium containing protein as sole nitrogen source, Aspergillus nidulans strain biAI synthesizes three neutral or alkaline extracellular proteases $(\alpha, \gamma, \epsilon)$ and one protease $(\beta)$ that is strictly intracellular. The four proteases are individually distinguishable by electrophoresis, inhibitorsensitivity, substrate-preference and $\mathrm{pH}$ optimum tests. When ammonium ion $(50 \mathrm{mM})$ is added to the medium, protease $\beta$ is synthesized as two precursors $(\beta \mathrm{I}$ and $\beta_{2}$ ) and synthesis of $\alpha, \gamma$ and $\epsilon$ is repressed. The precursors $\beta_{1}$ and $\beta_{2}$ can be separated by electrophoresis; they are weakly active at $50{ }^{\circ} \mathrm{C}$ and have no detectable activity in a protease assay. Conversion of $\beta$ I and $\beta_{2}$ to $\beta$ takes place during storage of mycelial extracts at $4{ }^{\circ} \mathrm{C}$; it is accompanied by the appearance of detectable activity in the protease assay. The intracellular enzyme $\gamma$ also occurs as an (active) precursor, $\delta$. Conversion of $\delta$ to $\gamma$ takes place both in vivo and in stored mycelial extracts, but does not occur in stored culture filtrates.

A recessive, single-gene mutation ( $x p r C I$ ), results in simultaneous loss of all extracellular proteases but $x p r C I$ strains grow and differentiate normally on medium containing non-protein nitrogen. Since the extracellular proteases are absent, both in $x p r C I$, and in biAI when grown in the presence of ammonium, it is concluded that they are not required for normal growth and differentiation. Also as $x p r C I$ does not utilize protein as sole nitrogen or carbon source, protease $\beta$ is not used in vivo to hydrolyse exogenous protein.
\end{abstract}

\section{INTRODUCTION}

Since it is easy to select fungal mutants with either enhanced or defective release of extracellular enzymes (Matile, 1965; Holliday \& Halliwell, 1968; Sekine, Nasumo \& Iguchi, 1969) the processes regulating synthesis and secretion of such enzymes should be amenable to genetic analysis.

In a previous paper (Cohen, 1972) methods were described for recognition of protease release by colonies of the filamentous fungus Aspergillus nidulans growing on solid media. It was shown that protease release is repressed by ammonium and other low-molecularweight nitrogen sources and the isolation of a mutant insensitive to ammonium repression was reported. In this paper the neutral and alkaline proteases of $A$. nidulans strain $b i A I$ are partially characterized and the isolation of a pleiotropic proteaseless mutant $(x p r C I)$ is described. It is shown that protease secretion is selective and that ammonium repression regulates the conversion of an intracellular protease from an inactive to an active form as well as the synthesis and secretion of the extracellular proteases. It is also shown that the extracellular enzymes are required for growth on protein as sole nitrogen or carbon source but are not required for normal growth and differentiation on medium containing non-protein nitrogen and glucose. 


\section{METHODS}

General techniques, media and strains. General techniques and minimal (MM) medium for Aspergillus nidulans were described by Pontecorvo et al. (1953). The strain biAI is a biotin-requiring derivative of the Glasgow wild-type and was Glasgow Stock strain number 05I (FGSC 26).

Growth conditions for release of extracellular protease. Mycelium was grown by inoculating liquid medium with $10^{6}$ washed spores/ml and incubating for 40 to $48 \mathrm{~h}$ at $37^{\circ} \mathrm{C}$ in static culture in a thin liquid layer (Cohen, I973). Since protease release is repressed by ammonium and other nitrogen sources, it was necessary to modify the standard MM. For colonies on solid media, growth without ammonium repression was obtained by omitting sodium nitrate and substituting $0.5 \%$ to I \% skimmed milk as sole nitrogen source ( $-\mathrm{N}$ milk medium; Cohen, 1972). This medium, without agar, has been used in the present study. Although the non-protein nitrogen in I \% skimmed milk did not repress protease release by $b i A I$, the stock (I0 $\%$, w/v) skimmed milk solution was dialysed overnight against running water before autoclaving. Undialysed milk was used for cultures of $x p r C I$.

Ammonium-repressed growth was obtained by addition of $50 \mathrm{~mm}$-ammonium (as tartrate) to $-\mathrm{N}$ milk (ammonium-milk medium).

Culture filtrates and mycelial extracts. Entire cultures of known volume, intended for subsequent assay of extracellular proteolytic activity, were filtered in sintered glass crucibles (Gallenkamp Ltd, London, porosity $\times 2$ ). The filtrate was used without further treatment as source of extracellular enzymes and the mycelium was dried overnight at $105^{\circ} \mathrm{C}$ and weighed after cooling over silica gel desiccant. Mycelium for subsequent protease assay or electrophoresis was harvested by suction on a sintered glass filter, washed with water, pressed dry with absorbent paper and its fresh weight measured. It was homogenized in Triton X-IOO (0.0I \%, v/v, in water; $0.4 \mathrm{ml} / 0 . \mathrm{I}$ g mycelium) using a Ten Broeck glass homogenizer (Corning Glass Co., New York, U.S.A.). Cell debris was removed by centrifugation at $3000 \mathrm{~g}$ for $\mathrm{I} 5 \mathrm{~min}$. This method is convenient for small quantities of mycelium (e.g. the product of $20 \mathrm{ml}$ medium) and achieves at least $50 \%$ cell breakage as estimated by phasecontrast microscopy.

Protease assay. Remazol Brilliant Blue Hide Powder (Calbiochem Ltd., London, WIH IAS) was finely ground and suspended $(8 \mathrm{mg} / \mathrm{ml})$ in I $\%$ skim milk buffered to $\mathrm{pH} 6.7$ with $0.05 \mathrm{M}$-tris-maleate. The sample to be assayed $(0.1 \mathrm{ml})$ was added to prewarmed substrate $(\mathrm{I} \cdot 0 \mathrm{ml})$ and after incubation at $45{ }^{\circ} \mathrm{C}$ for $30 \mathrm{~min}$ with continuous magnetic stirring the reaction was stopped with trichloroacetic acid $(20 \%, \mathrm{w} / \mathrm{v} ; 0.25 \mathrm{ml})$. Undigested protein was deposited by centrifugation at $3000 \mathrm{~g}$ for $15 \mathrm{~min}$ and the optical density of the supernatant measured $(\lambda=595 \mu \mathrm{m})$. In this method the entire assay is carried out in one tube, avoiding the cumbersome filtration step of the original method (Rinderknecht, Geokas, Silverman \& Haverback, I968). Optical density was proportional to trypsin concentration within the range measured.

Protease activity is expressed in arbitrary units; I unit $=0.1 \mathrm{mg}$ dye-protein solubilized. Specific activity is expressed as units/g fresh wt of mycelium in the case of mycelial extracts or, in the case of culture filtrates, as units/mg dry wt of mycelium, referring to the total mass of mycelium in the culture from which the filtrate was obtained. The two specific activities may not, therefore, be directly compared.

Electrophoresis of mycelial extracts and culture filtrates. The detection, after electrophoresis, of a mixture of proteases of unknown specificities requires a substrate film method (Daoust, 1965) in which enzymes diffuse from a supporting medium into a layer of agar 
containing a substrate protein, hydrolysis of which can be detected by suitable means after joint incubation. Starch and acrylamide gels and cellulose acetate sheet were tested as electrophoretic supporting media followed by detection of proteases by diffusion into I \% milk protein agar films. The greatest sensitivity of detection was obtained with cellulose acetate. Comparison of separations in the three supporting media showed that resolution in cellulose acetate was adequate. This method was therefore adopted.

Cellulose acetate sheet (Celagram, $78 \times 150 \mathrm{~mm}$, Shandon Scientific Co. Ltd, London) was used as described by Kohn (1958). The electrophoresis buffer contained: tris, $0.50 \mathrm{M}$; boric acid, 0.075 M; di-NaEDTA, 0.0 I6 M, pH 9. I (Aronsson \& Grönwall, I957). A voltage gradient of $\mathrm{I} \cdot 7 \mathrm{~V} / \mathrm{mm}$ was applied for $45 \mathrm{~min}$ during which the fastest-moving protease migrated about $45 \mathrm{~mm}$ to the anode. Samples $(\mathrm{I} \cdot 3 \mu \mathrm{l} / \mathrm{mm})$ were applied using a calibrated microcapillary (Ziptrol, Drummond Scientific Co. Ltd, Broomall, Pennsylvania, U.S.A.) to origins placed $15 \mathrm{~mm}$ from the cathode end.

After electrophoresis the cellulose acetate sheet was placed in contact with the substrate film and incubated for $3 \mathrm{~h}$ at $50^{\circ} \mathrm{C}$. Because of electrophoresis buffer in the sheet the $\mathrm{pH}$ during incubation was about $8 \cdot 8$. After incubation the sheet was removed and the substrate film was stained with $\mathrm{I} \%(\mathrm{w} / \mathrm{v})$ Naphthalene Black Io B in acetic methanol solution, decolorized with the same solvent mixture and dried in air at $50{ }^{\circ} \mathrm{C}$. Quantitative estimates of protease activity relative to a standard were made by scanning the substrate film with a recording micro-densitometer (Joyce-Loebl Co. Ltd, Gateside, Durham).

Detection of alkaline proteases. Portions ( $10 \mathrm{ml}$ ) of $10 \%(\mathrm{~W} / \mathrm{v})$ skim milk, $10 \mathrm{ml}$ of $\mathrm{I} \cdot \mathrm{O} \mathrm{M}-$ phosphate buffer, $\mathrm{pH} 8 \cdot 6$, and $0.2 \mathrm{~g}$ sodium azide were added to $100 \mathrm{ml}$ of molten $2 \%$ agar. A $10 \mathrm{ml}$ portion of the mixture was pipetted on to a heated glass plate $(150 \times 100 \times \mathrm{I} \cdot 5 \mathrm{~mm})$ and spread to the edges with a heated glass-rod spreader. Films were used as soon as the agar had set, or stored at room temperature in an airtight container.

Detection of neutral proteases. For this purpose the substrate film was buffered to $0.2 \mathrm{M}$ with tris-maleic acid-sodium hydroxide, $\mathrm{pH}^{\circ} \cdot 0$ or 6.5 . After the cellulose acetate sheet had been laid on the substrate film it was covered with a sheet of Cellophan $(0.004$ in thick, British Cellophan Ltd, London W I) which had been soaked in the same buffer and lightly dried. The Cellophan was then overlaid with molten $0.2 \mathrm{M}$-buffered agar. At the conclusion of the incubation period the Cellophan, agar overlay and cellulose acetate sheet were discarded and the substrate film stained as usual. Narrow-range $\mathrm{pH}$ papers applied to the agar indicated that the actual $\mathrm{pH}$ of incubation was about 0.5 units higher than that of the buffer used. It was thus possible to detect proteases active at $\mathrm{pH} 5.5$ and 6.5 whilst retaining optimal electrophoretic separation.

Substrate specificity of proteases. This was investigated by substituting other proteins for milk in the substrate films. The soluble proteins albumin, gelatin and haemoglobin were used at $\mathrm{i} \%(\mathrm{w} / \mathrm{v})$ final concentration.

Inhibitor sensitivity of proteases. This was determined by pre-incubating mycelial extract or culture filtrate with inhibitor, followed by electrophoresis under standard conditions. When inhibition was not complete the degree of inhibition was estimated from microdensitometer tracings. The conditions of treatment with each inhibitor are given in Table I.

Isolation of extracellular proteaseless mutants. Mutations were induced by ultraviolet light irradiation of conidia from Glasgow stock strain oro2 treated to give approximately $10 \%$ survival. Treated conidia were held in the dark for $\mathrm{I} h$ at $6{ }^{\circ} \mathrm{C}$, then spread on $-\mathrm{N}$ milk medium supplemented with the nutrients required by the strain. Sodium deoxycholate $(0.09 \%, w / v)$ was added to induce microcolony formation (Mackintosh \& Pritchard, 1963) and tris-maleic acid buffer, $\mathrm{pH} 8.5$, was added (final concentration $0.01 \mathrm{M}$ ) to prevent the 


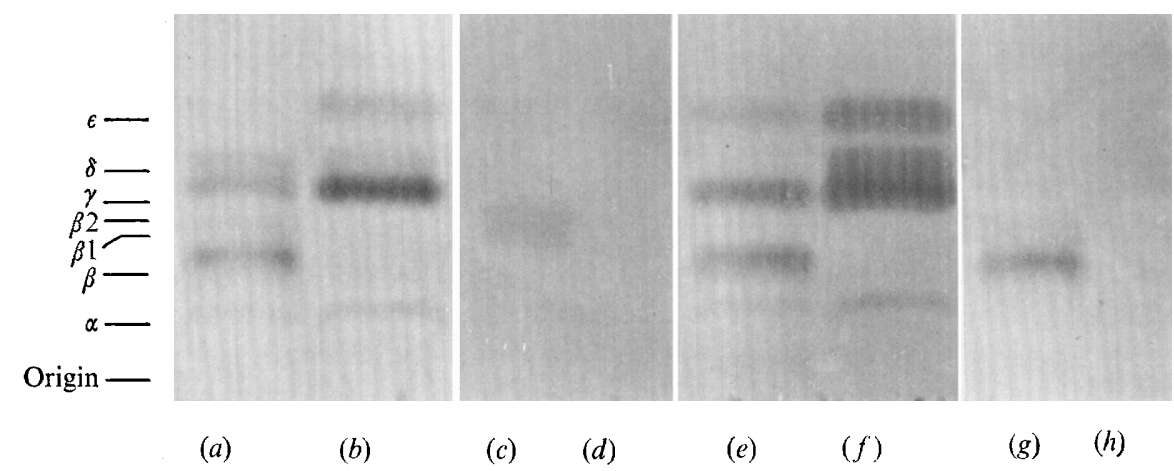

Fig. I. Neutral and alkaline proteases of Aspergillus nidulans. Contact prints of substrate films; zones of protease activity appear dark. The electrophoretic origin is indicated.

$(a)$ and $(b)$. Strain biAI. Fresh mycelial extract $(a)$ and culture filtrate $(b)$ of culture grown on $-\mathbf{N}$ milk medium (derepressed).

$(c)$ and $(d)$. Strain biAr. Fresh mycelial extract $(c)$ and culture filtrate $(d)$ of culture grown on 50-mm ammonium milk medium (repressed).

$(e)$ and $(f)$. Strain biAI. Mycelial extract $(e)$ and culture filtrate $(f)$ from a derepressed culture (not the same as samples shown in $(a)$ and $(b)$ ). The extract and filtrate were kept at $4{ }^{\circ} \mathrm{C}$ for 8 days before electrophoresis.

$(g)$ and $(h)$. Strain $x p r C I$. Mycelial extract $(g)$ and culture filtrate $(h)$ of culture grown on $-\mathrm{N}$ milk. medium (derepressed).

formation of haloes due to deoxycholate solubilization and thereby permit detection of haloes due to milk-clearing by protease. Colonies without a distinct zone of milk clearing were picked after 48 to $72 \mathrm{~h}$ growth at $37^{\circ} \mathrm{C}$. Mrs Etta Dunn developed this method for distinguishing the two sorts of halo that can form on this medium.

Genetic analysis. Only one proteaseless mutant, $x p r C I$, will be referred to in this paper. This mutant was isolated and located to linkage group VIII (McCully \& Forbes, 1965) by Mrs Etta Dunn. It was recessive in heterokaryon and heterozygous diploid and segregated in crosses as a single gene mutation. $x p r C I$ strains grew and differentiated normally on $\mathrm{MM}$, on ammonium-milk medium and on $-\mathrm{N}$ milk medium containing undialysed milk. On $-\mathbf{N}$ milk medium containing dialysed milk or on $-\mathbf{N}$ milk medium containing dialysed milk but without glucose, $x p r C I$ strains showed the sparse growth typical of nitrogen or carbon starvation.

Analysis of the cross, pabaAI, yA2; pyroA4; xprCI, ornB2 $\times$ biAI; fwAI, located $x p r C I$ between $f w$ and orn.

\section{RESULTS}

The proteases of biAI

The mycelial and extracellular protease activities of biAI grown in the presence and absence of ammonium are shown in Fig. I $(a-d)$ and Table I. Cultures grown in the presence of ammonium will be referred to as 'repressed' and those grown in the absence of ammonium as 'derepressed'.

Extracts and filtrates of repressed cultures contained no proteolytic activity detectable by assay. Electrophoresis revealed the presence of proteases $\beta_{I}$ and $\beta_{2}$ in mycelial extracts but no proteases in culture filtrates.

Extracts and filtrates of derepressed cultures contained high proteolytic activity. Electrophoresis revealed that proteases $\alpha, \gamma, \delta$ and $\epsilon$ occurred in both extracts and filtrates whilst proteases $\beta, \beta_{1}$ and $\beta_{2}$ occurred only in mycelial extracts. 
Table I. Extracellular and intracellular protease activity of wild-type and proteaseless mutant strains of Aspergillus nidulans

$\begin{array}{clcc}\text { Strain } & \begin{array}{c}\text { Culture } \\ \text { conditions* }\end{array} & \begin{array}{c}\text { Mycelial extract } \\ \text { (units/g fresh wt } \\ \text { mycelium) }\end{array} & \begin{array}{c}\text { Culture filtrate } \\ \text { (units/mg dry wt } \\ \text { mycelium) }\end{array} \\ \text { biaI } & \text { Ammonium-repressed } & \text { o (fresh) } & \text { o (fresh) } \\ & \text { Ammonium-derepressed } & 15 \text { (aged) } & \circ \text { (aged) } \\ x p r C I & \begin{array}{c}\text { Ammonium-repressed } \\ \text { Ammonium-derepressed }\end{array} & 0 & 48 \\ & & 10 & 0\end{array}$

* As specified in Methods.

Table 2. Responses of Aspergillus nidulans neutral and alkaline proteases to inhibitors

\begin{tabular}{|c|c|c|c|c|c|c|c|}
\hline \multirow[b]{2}{*}{ Inhibitor* } & \multirow{2}{*}{$\begin{array}{l}\text { Final } \\
\text { concentra- } \\
\text { tion }\end{array}$} & \multirow{2}{*}{$\begin{array}{l}\text { Duration and } \\
\text { temperature of } \\
\text { treatment }\end{array}$} & \multicolumn{5}{|c|}{$\begin{array}{l}\text { Activity and electrophoresis of } \\
\text { protease } \uparrow\end{array}$} \\
\hline & & & $\alpha$ & $\beta$ & $\gamma$ & $\delta$ & $\epsilon$ \\
\hline $\begin{array}{l}\text { Di-isopropyl-fluorophosphate } \\
\text { (DIFP) }\end{array}$ & $10^{-2} \mathrm{M}$ & $\begin{array}{l}20 \mathrm{~h} \text { at } 2{ }^{\circ} \mathrm{C} \text { and } \mathrm{I} h \text { at } \\
37^{\circ} \mathrm{C}\end{array}$ & + & $(t)$ & - & - & - \\
\hline $\begin{array}{l}\text { Phenylmethyl-sulphonylfiuoride } \\
\text { (PMSF) }\end{array}$ & $2.5 \mathrm{mg} / \mathrm{ml}$ & I h at $37^{\circ} \mathrm{C}$ & + & - & - & NT & + \\
\hline $\begin{array}{l}N-\alpha-p \text {-Tosyl-L-Lysine } \\
\text { chloromethyl ketone (TLCK) }\end{array}$ & $2.5 \mathrm{mg} / \mathrm{ml}$ & I h at $37^{\circ} \mathrm{C}$ & + & + & + & + & - \\
\hline $\begin{array}{l}\text { Ethylenediamine tetra-acetic } \\
\text { acid (EDTA) }\end{array}$ & $\mathrm{I} \cdot 6 \times 10^{-2} \mathrm{M}$ & $\begin{array}{c}\text { During electrophoresis } \\
\text { only: } 45 \text { min at } 20^{\circ} \mathrm{C}\end{array}$ & $\begin{array}{l}+ \\
\text { Stays at origin } \\
\text { when EDTA o }\end{array}$ & + & + & + & + \\
\hline Chicken ovoinhibitor & $2.5 \mathrm{mg} / \mathrm{ml}$ & I h at $37^{\circ} \mathrm{C}$ & + & - & & NT & - \\
\hline
\end{tabular}

* Mycelial extracts or culture filtrates were incubated with inhibitors under the conditions shown before electrophoresis and detection of proteolytic activity. The following compounds were without effect when incubated with protease for $\mathrm{I} \mathrm{h}$ at $37^{\circ} \mathrm{C}$, final concentrations $2.5 \mathrm{mg} / \mathrm{ml}$ : chicken ovomucoid, iodoacetate, mercaptoethanol, $p$-chloromercuribenzoate, sodium azide, I-tosylamide-2-phenylethyl-chloromethane ketone (TPCK). DIFP was dissolved in dry isopropanol, PMSF, TLCK and TPCK in dimethyl-sulphoxide. These solvents were found to be without inhibiting effect on the proteases when present at the final concentrations used.

$\dagger+$ (full activity) and - (complete inhibition) were judged from the results of electrophoresis. $(+)$ indicates I0 \% activity measured by densitometry of substrate gel plates. NT indicates not tested.

Electrophoresis of mycelial extracts that had been stored at $4{ }^{\circ} \mathrm{C}$ revealed that proteases $\alpha, \gamma$ and $\epsilon$ were stable whereas $\beta \mathrm{I}, \beta_{2}$ and $\delta$ were labile (Fig. I $a, f$ ). Proteases $\beta \mathrm{I}$ and $\beta_{2}$ disappeared progressively and were replaced by protease $\beta$ with increase in total activity (Table I). Disappearance of $\delta$ during storage was accompanied by increase in $\gamma$ but probably no increase in total activity. Conversion of $\beta$ I to $\beta$ and $\delta$ to $\gamma$ has also been observed to occur in vivo (A. J. Clutterbuck, personal communication). No evidence exists at present to indicate the mechanism of these transformations except that the $\delta$ to $\gamma$ shift did not occur in cell-free culture filtrates (Fig. I $f$ ); it must therefore require a factor (possibly protease $\beta$ ) present only in mycelial extracts.

The responses of the proteases to inhibitors and their activities against different protein substrates at varying $\mathrm{pH}$ are given in Tables 2 and 3. These tests show that proteases $\alpha$, $\beta, \gamma$ and $\epsilon$ are functionally different enzymes, but do not distinguish between $\gamma$ and $\delta$. $\beta$ I and $\beta 2$ were not tested. 
Table 3. Hydrolysis of protein substrates by Aspergillus nidulans neutral and alkaline proteases

\begin{tabular}{|c|c|c|c|c|c|}
\hline \multirow{2}{*}{$\begin{array}{l}\text { Substrate } \\
\text { protein }\end{array}$} & \multirow{2}{*}{$\begin{array}{c}\mathrm{pH} \text { of } \\
\text { incubation }\end{array}$} & \multicolumn{4}{|c|}{ Relative activities of proteases* } \\
\hline & & $x$ & $\beta$ & $\gamma$ & $\epsilon$ \\
\hline Casein (milk) & $\begin{array}{l}5 \text { to } 6 \\
8 \text { to } 9\end{array}$ & - & $\begin{array}{l}++ \\
++\end{array}$ & $\begin{array}{l}++ \\
++\end{array}$ & $\bar{t}$ \\
\hline Gelatin & $\begin{array}{l}5 \text { to } 6 \\
8 \text { to } 9\end{array}$ & $\begin{array}{l}- \\
-\end{array}$ & $\begin{array}{l}+ \\
++\end{array}$ & $\begin{array}{c}+ \\
++\end{array}$ & - \\
\hline Haemoglobin & $\begin{array}{l}5 \text { to } 6 \\
8 \text { to } 9\end{array}$ & - & $\begin{array}{l}- \\
+\end{array}$ & $\begin{array}{l}+ \\
+\end{array}$ & - \\
\hline
\end{tabular}

The proteases of $x p r C I$

Filtrates of $48 \mathrm{~h}$ derepressed cultures of this strain contained no protease activity detectable by direct assay or by electrophoresis. Mycelial extracts contained protease $\beta$ but $\alpha, \gamma, \delta$ and $\epsilon$ were completely absent (Fig. I $g, h$; Table I). However, other proteaseless mutants selected in the same way as $x p r C I$ did not have this very distinctive phenotype. Whatever the explanation of the multiple phenotypic loss in $x p r C I$, the normal growth and differentiation of this mutant on ammonium-milk and minimal media establishes that the missing proteases are not essential for growth and differentiation and confirms the functional distinction already drawn between the strictly intracellular protease $\beta$ and the other, potentially extracellular, enzymes.

\section{DISCUSSION}

The proteases of aspergilli and other fungi have been the subject of many investigations, reviewed by Matsubara \& Feder (1971). This review indicates that most fungi are able to synthesize three classes of proteolytic enzymes: (i) pepsin-like acid proteases; (ii) DIFPsensitive neutral and alkaline proteases; and (iii) metal-ion-dependent neutral or alkaline proteases. The existence of zymogen-like precursors has also been noted occasionally. It is not clear how the synthesis and release of these enzymes are regulated or whether there are differences amongst the proteases in relation to function in vivo. Neither has the requirement of the proteases for normal growth and differentiation been established.

From the results described here it can be concluded that the proteases of Aspergillus nidulans are broadly similar to those of related fungi, the failure to detect acid protease being most probably a consequence of the methods used. The use of zone electrophoresis with direct detection of the separated enzymes permitted the recognition of two precursorproduct groupings amongst the proteases and the unambiguous identification of protease $\beta$ as a strictly intracellular component. It also made possible the unique observation (Table 2) that the mobility of protease $\alpha$ is altered by treatment with EDTA, presumably as the result of the removal of cations from a weak binding site that is not essential for function. Possibly prolonged treatment at high EDTA concentration would inactivate this enzyme (Sekine, 1972). Also, electrophoresis has revealed that protease $\gamma$ interacts with chicken ovoinhibitor without inhibition, at least under the conditions used for detection of proteolytic activity after electrophoresis.

A proper account of the two protease precursor-product complexes must await a biochemical study of purified proteins. It is reasonably clear, however, that the conversion of $\beta \mathrm{I}$ and $\beta_{2}$ to $\beta$ is a zymogen-like activation, since mycelial extracts containing only $\beta \mathrm{I}$ and 
$\beta_{2}$ have a level of proteolytic activity that is too low to be measured, whereas the same extracts after storage contain $\beta$ and have measurable activity. If $\beta_{1}$ and $\beta_{2}$ are indeed zymogens their detection as weakly active proteolytic zones after electroophoresis is a novel observation. It could result either from autocatalytic activation in situ or from slight intrinsic activity in the unusual conditions $\left(3 \mathrm{~h}\right.$ at $\left.50^{\circ} \mathrm{C}\right)$ used for protease detection. The conversion of $\delta$ to $\gamma$ does not appear to cause an increase in proteolytic activity and may therefore be an enzymatic modification. It is notable that this conversion in vitro is dependent upon an activity present in cell extracts but absent from culture fitrates. Whether this is also true of the $\beta$ conversion cannot be determined until purified $\beta$ I and $\beta_{2}$ are available.

Regulation of the release of protease by ammonium repression has been established (Cohen, 1972) and from the results reported here it appears that the effects of ammonium also include repression of the synthesis of proteases $\alpha, \beta, \gamma, \delta$ and $\epsilon$ and the maintenance of a low level of $\beta$ in its precursor forms. It is not yet clear whether ammonium repression also determines the synthesis of $\gamma$ in its precursor form $\delta$. A more detailed account of these effects is in preparation. The absence of all $\alpha, \gamma, \delta$ and $\epsilon$ activities from ammonium-repressed mycelium appears to establish that these proteases are not essential for macroscopically normal growth and differentiation, a conclusion strengthened by normal growth of the mutant $x p r C r$.

The occurrence of protease $\beta$ in only its precursor forms in mycelium grown under repressing conditions is most interesting, since it implies both that the activation of the precursors is regulated by ammonium repression and that active $\beta$, despite its strictly intracellular location, is not essential for normal growth. It will be interesting to discover which of the proteases of Aspergillus nidulans is concerned with protein turnover and how ammonium derepression initiates the conversion of $\beta$ I and $\beta 2$ to $\beta$.

Finally, it should be noted that in $x p r C I$, which is unable to utilize protein as sole nitrogen or carbon source, protease $\beta$ responds normally to ammonium repression. These results imply that protease $\beta$ is in a cell compartment that cannot gain access to extracellular protein and that the mutational defect in this strain affects protease synthesis, release, or both rather than ammonium repression. It seems reasonable to expect that further study of this and other mutants defective in extracellular enzyme production may contribute to analysis of the secretion process and its control.

I am grateful to Dr John Beeley, Department of Biochemistry, University of Glasgow, for a gift of pure chicken ovomucoid, to Dr John W. Donovan, Western Regional Research Laboratory, U.S. Department of Agriculture, Albany, California, for a gift of pure chicken ovoinhibitor, to Mrs Etta Dunn for the isolation of xprCI, and to Miss Moira Hogg for excellent technical assistance.

\section{REFERENCES}

Aronsson, T. \& Grönwall, A. (1957). Improved separation of serum proteins in paper electrophoresis - a new electrophoresis buffer. Scandinavian Journal of Clinical and Laboratory Investigation 9, 338-34I.

CoHen, B. L. (1972). Ammonium repression of extracellular protease in Aspergillus nidulans. Journal of General Microbiology 71, 293-299.

CoHen, B. L. (1973). Growth of Aspergillus nidulans in a thin liquid layer. Journal of General Microbiology $76,277-282$.

Daoust, R. (1965). Histochemical localisation of enzyme activities by substrate film methods. In International Review of Cytology, vol. I8, pp. 19I-22I. Edited by G. H. Bourne and J. F. Danielli, New York and London: Academic Press.

Holliday, R. \& Halliwell, R. E. (1968). An endonuclease-deficient strain of Ustilago maydis. Genetical Research 12, 95-98. 
KoHN, J. (1958). Membrane filter electrophoresis. In Protides of the Biological Fluids, Proceedings of the 5 th Colloquium, Bruges, 1957, pp. I 20-1 25. Edited by H. Peters. Amsterdam: Elsevier.

Mackintosh, M. E. \& Pritchard, R. H. (1963). The production and replica plating of micro-colonies of Aspergillus nidulans. Genetical Research 4, 320-322.

MCCULLY, K. S. \& FoRBES, E. (1965). The use of $p$-fluorophenylalanine with 'master strains' of Aspergillus nidulans for assigning genes to linkage groups. Genetical Research 6, 352-359.

MATILE, P. (1965). Intrazelluläre Lokalisation proteolytischer Enzyme von Neurospora crassa. I. Funktion und subzelluläre Verteilung proteolytischer Enzyme. Zeitschrift für Zellforschung und mikroskopische Anatomie 68, 205-216.

Matsubara, H. \& Feder, J. (1971). Other bacterial, mold and yeast proteases. In The Enzymes, 3rd edn, pp. 72I-795. Edited by P. D. Boyer. New York and London: Academic Press.

Pontecorvo, G., Roper, J. A., Hemmons, L. M., MacDonald, K. D. \& Bufton, A. W. J. (1953). The genetics of Aspergillus nidulans. Advances in Genetics 5, I4I-238.

Rinderknecht, H., Geokas, M. C., Silverman, P. \& HaVerback, B. J. (I968). A new ultrasensitive method for the determination of proteolytic activity. Clinica chimica acta 2I, 197-203.

Serine, H. (1972). Neutral proteinases I and II of Aspergillus sojae: some enzymatic properties. Agricultural and Biological Chemistry 36, 207-216.

Sexine, H., NAsUmo, S. \& IGUCHI, N. (I969). Isolation of highly proteolytic mutants of Aspergillus sojae. Agricultural and Biological Chemistry 33, I477-1482. 